
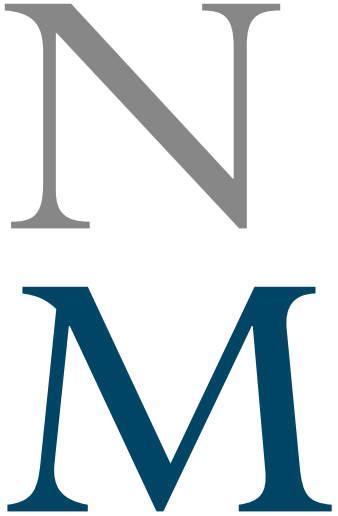
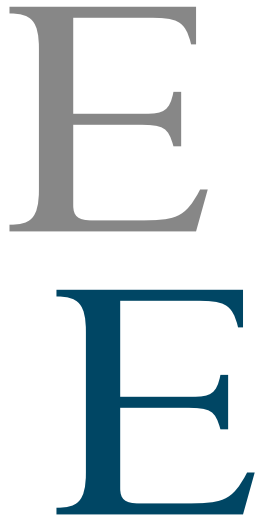
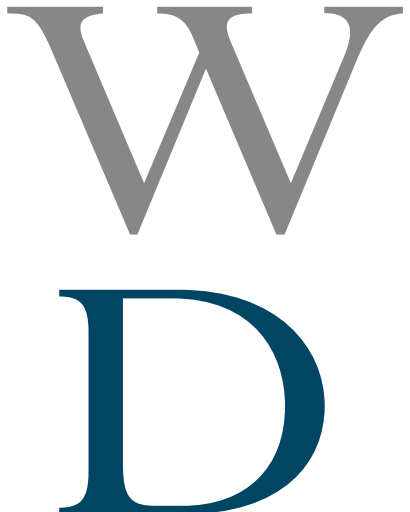
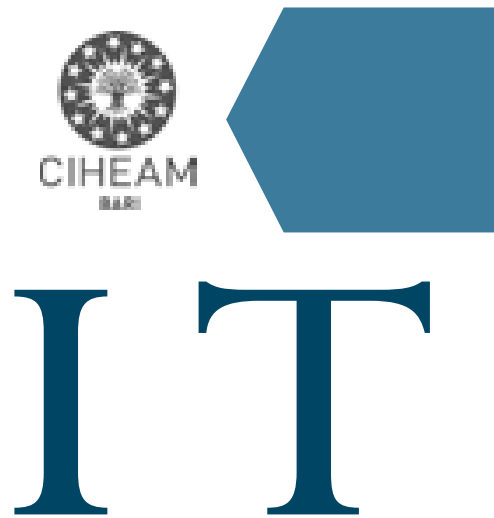

MEDITERRANEAN JOURNAL OF ECONOMICS, AGRICULTURE AND ENVIRONMENT

Poste Italiane Spa Spedizione in Abbonamento Postale Periodico ROC Centro Nord aut. $\mathrm{N}^{\circ} 0029-€ 15,00$.

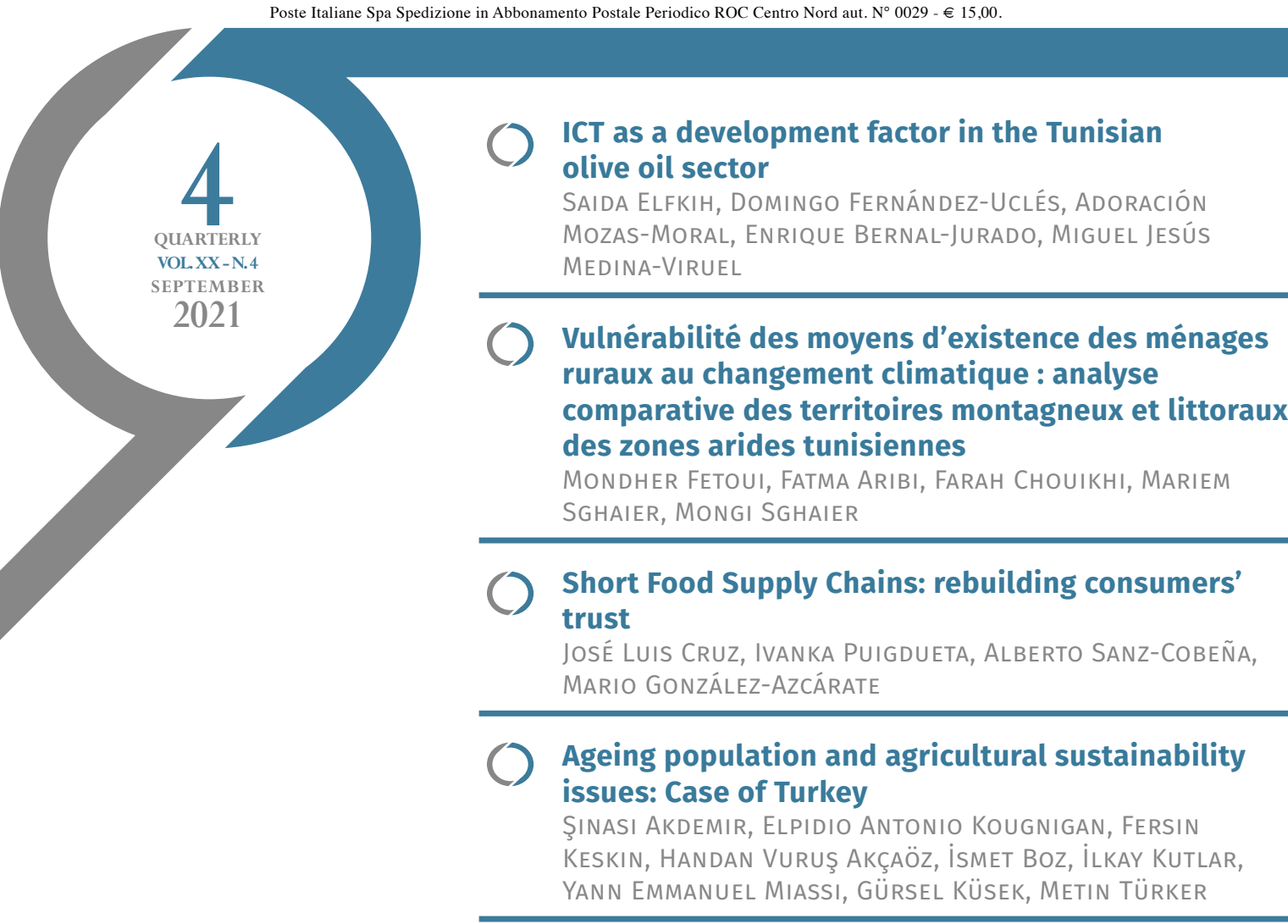




\title{
Non-financial factors affecting livestock farm's performance in meat supply chain
}

\author{
Gentjan Mehmetı*, Raffaele Zanoli**, Orjon Xhoxhı*
}

DOI: $10.30682 / \mathrm{nm} 2104 \mathrm{e}$

JEL codes: M11, Q12, Q19

\begin{abstract}
This article investigates non-financial factors affecting performance of livestock farms in the meat supply chain in Albania.

A structured questionnaire was developed to collect data in three main regions of Albania (Tirana, Korça and Lushnje). Confirmatory factor analysis is used to develop measures for the non-financial factors (i.e. trust, contracts, opportunistic behavior, information sharing and information quality) and Structural Equation Modelling is employed to test study hypotheses.

The result shows that trust is positively associated with farm's performance. On the other hand, communication (i.e. resulting from the merge of information sharing and information quality) is negatively associated with performance. However, communication appears to have a positive association with farm's performance indirectly through its effect on trust. Thus, it can be deducted that communication builds trust and trading relationship based on trust show higher levels of farm's performance. Lastly, contracts and opportunistic behavior do not show any significant association with farm's performance.
\end{abstract}

Keywords: Farm, Livestock, Meat, Supply chain, Non-financial factors, Performance, Structural equation modelling.

\section{Introduction}

After 46 years of centralized economy Albanian agriculture has changed significantly since the early 1990s. In the socialist era due to collectivization there have been 550 large state farms and cooperatives, but after the collapse of the socialist system and land distribution were created about 467000 small family farms. In 2014, the number of farms in Albania was 352315 with an average size of 1.16 ha (INSTAT, 2014). Family farms, as a result of the implementation of economic reforms in Albanian agriculture and the establishment of private ownership of land, are characterized by land fragmentation, financial difficulties in securing production inputs and lack of information, leading to a lack of farmers' bargaining power (Meço et al., 2017). Also, Fetoui et al. (2020) referring to olive oil producers in Tunisia, states that land fragmentation, results in a lack of bargaining power. According to Markhof et al. (2010), the market driven economy forced Albanian farmers to change production patterns and major moves were made towards livestock production.

Livestock is the sector that has had the greatest development during the transition years where the number of heads and production has increased. According to national accounts' statistics for livestock,

\footnotetext{
* Agricultural University of Tirana, Albania.

** Università Politecnica delle Marche, Italy. Corresponding author: gmehmeti@ubt.edu.al
} 
meat domestic production in Albania is dominated by cattle production which accounts for $45 \%$ of the total meat produced domestically. Meat consumption is already at $40 \mathrm{~kg}$ per capita (Markhof et al., 2010). Meat exports are low, whereas imports of live animals are increasing, particularly the cattle and pigs. Imports of pork meat are quite high as well. The meat industry was the first agro-industrial sector to consolidate and develop, but it is focused on the domestic market.

Livestock is one of the main sector of agricultural development in Albania and it has a significant contribution to Gross Domestic Product (GDP). It is considered as a priority for development due to country favorable livestock breeding conditions, but its performance is still below optimal level. Performance is a concept that has multidimensional aspects. Financial and non-financial factors play a role in farm performance (Gunasekaran et al., 2001; Kim, 2009).

The aim of this study is to identify how the non - financial factors impact the performance of livestock farms. A model to assess the contribution of each factor in the performance of these farms in the meat supply chain was build. Data was collected in three main districts of Albania (Tirana, Korça and Lushnje), as these three districts have a large number of livestock farms for cattle, small ruminants and pig breeding. The study applied Structural Equation Modelling (SEM) to investigate the causal relationships between some relevant factors and hypothesis testing.

To the authors' knowledge there is no similar study realized to evaluate the livestock farm performance. Latruffe and Piet (2014) have analyzed the impact of land fragmentation on farm performance, while Bojnec and Latruffe (2013) have investigated the relationship between farms size, subsidies and farm performance. Also, there is no similar study published previously in Albania in identifying and evaluating the contribution of non-financial factors on the performance of livestock farms. It should be noted that studies on this sector are mainly in the context of descriptive studies or focused on a specified meat subsector (for instance: Kipi et al., 2010; Kristo and Leonetti, 2005; Kristo and Leonetti, 2010).

This paper is organized as follows. Section two reviews the literature on performance and non - financial factors that affect the performance. Section three describes the materials and methods used in this study, followed by hypothesis testing and research results. The paper ends with discussion and conclusion section.

\section{Literature review on non-financial factors affecting farm performance}

To better understand the factors that affect performance, first it is needed to measure it. Performance measurement involves the use of a multidimensional set of metrics, including financial and non-financial metrics (Gunasekaran et al., 2001); internal and external, as well as metrics that measure what has been achieved so far, or metrics that will help to predict what can happen in the future (Bourne et al., 2003). Furthermore, Gunasekaran et al. (2001) reviewed the literature on the supply chain performance metrics and concluded that there is not a balanced approach to financial and non-financial measures or to the number of performance indicators used.

Kim (2009) in the performance analysis of firms used financial and non-financial factors, relying on market-based performance, financial performance, as well as customer service. Cao and Zhang (2011) used sales growth, profit margin on sales, return on investment and increased return on investment to measure the performance in the supply chain. While Prajogo and Olhager (2012) in their study used production costs as one of the elements for measuring performance.

As mentioned above, this study will seek to evaluate the performance of livestock farms in the meat supply chain in Albania. In this context, the performance of livestock farms is measured through: sales revenue, production cost and the herd size, which is a measure built by the authors due to the nature of the study. Regarding the factors affecting farm performance, several factors have been identified from literature such as: trust, contracts, opportunistic behavior, information sharing and information quality.

\section{Trust}

According to Fynes and Voss (2002) trust is the foundation for business transactions because its presence creates a better working environment 
by reducing contract specifications, providing incentives for collaboration or reducing uncertainty. Jap and Anderson (2003) would point out that trust is one of the most well-known mechanisms for governing the exchange relations. It is a key factor for developing partnerships between supply chain agents (Johnston et al., 2004); it promotes long-term, mutually satisfactory and profitable relationships (Ganesan, 1994; Grewal et al., 1999); reduces opportunistic behavior (Morgan and Hunt, 1994) and can act as a substitute for contracts (Lui and Ngo, 2004). According to Nevis and Money (2006) trust is expected to have a positive direct impact on performance, and it improves both buyer and seller commitment (Geyskens et al., 1996). Therefore, the proposed hypothesis is:

Hypothesis 1: Trust between farmers and their buyers is positively associated with farm's performance.

\section{Contracts}

To achieve a better management of the buyer-seller relationship supply chain members are coordinated using contracts, which according to Nevis and Money (2006) state how the parties will have to behave. According to Lusch and Brown (1996) contracts can also be seen as an opportunity to reduce risk and insecurity, and have been suggested as improving channel profitability by enabling coordinating efforts of channel members. Therefore, the hypothesis raised by this study for contract is the following: Hypothesis 2: The existence of contracts between farmers and their buyers is positively associated with farm's performance.

\section{Opportunistic behavior}

Opportunistic behavior is defined as a behavior in the pursuit of self-interest with stealing, lying, cheating, distorting, misleading (Williamson, 1975). At worst, opportunistic behavior is intended to cause harm, while in the best case it totally ignores the influence of others (Lai et al., 2005; MacNeil, 1981). It should be noted that if there is little opportunism among supply chain members, the performance will be improved by trust; however, when opportunism is high, the positive impact of trust on performance is significantly reduced (Jap and Anderson, 2003).
A concept related to the opportunistic behavior is that of bargaining power. Bargaining power can be defined as a party ability "to obtain a concession from another party by threatening to impose a cost, or withdraw a benefit, if the party does not grant the concession" (Kirkwood, 2005). Xhoxhi et al. (2019) points out that farmers are reluctant to engage in contract farming with buyers with high bargaining power due to "fear" of intermediaries' opportunistic behavior which can result in extraction of higher rents from farmers' specific investments. In the same line, Sorrentino et al. (2018) argues that in bargaining power models one can account for opportunistic behavior.

Seeing that opportunistic behavior appears as an unfair behavior for maximizing self-interest, we can say that it will negatively affect performance. The proposed hypothesis is:

Hypothesis 3: Buyers' opportunistic behavior towards farmers is negatively associated with farm's performance.

\section{Information sharing}

Information sharing refers to the mass of critical information transmitted to one of the supply chain members (Monczka et al., 1998). In fact, for many authors, information sharing among members of a supply chain is of great importance. For Lalonde (1998) information sharing is considered as one of the pillars that characterize a consolidated relationship in a supply chain. Lee et al. (2000) indicate that the potential benefits that may come from information sharing for producers may be: cost and inventory reduction. Marshall and Bly (2005) argue that the shared information builds and strengthens the relationship between the provider and the recipient of the information. Therefore, the hypothesis raised for information sharing is as follows:

Hypothesis 4: Information sharing between farmers and their buyers is positively associated with farm's performance.

\section{Information quality}

According to Prajogo and Olhager (2012) it is important both the quantity and the quality of the shared information. With information quality we will understand aspects related to the ac- 
Table 1 - Mean, Standard Deviation (SD) and Cronbach's Alpha for each item.

\begin{tabular}{|c|c|c|c|}
\hline & Mean & $S D$ & $\begin{array}{l}\text { Cronbach's } \\
\text { Alpha }\end{array}$ \\
\hline Information Sharing & & & .977 \\
\hline My buyer shares confidential information with me. & 2.70 & 1.17 & \\
\hline Information sharing between me and my buyer is done on time. & 2.73 & 1.18 & \\
\hline My buyer provides information that can help me. & 2.69 & 1.11 & \\
\hline $\begin{array}{l}\text { In the business relationship with my buyer, we keep each other } \\
\text { informed of events or changes that may affect the other party. }\end{array}$ & 2.77 & 1.16 & \\
\hline I share confidential information with my buyer. & 2.73 & 1.21 & \\
\hline Trust & & & .930 \\
\hline My buyer keeps his promises. & 3.12 & 1.05 & \\
\hline My buyer does not make false promises. & 3.09 & 1.07 & \\
\hline I trust my buyer. & 3.08 & 1.06 & \\
\hline My buyer does not take action that could damage my business. & 3.25 & 1.04 & \\
\hline Information Quality & & & .947 \\
\hline The exchange of information between me and my buyer is accurate. & 3.40 & 1.02 & \\
\hline The exchange of information between me and my buyer is complete. & 3.30 & 0.98 & \\
\hline $\begin{array}{l}\text { The exchange of information between me and my buyer is done } \\
\text { at the right time. }\end{array}$ & 3.33 & 0.96 & \\
\hline The exchange of information between me and my buyer is trustworthy. & 3.34 & 1.01 & \\
\hline Opportunistic Behavior & & & .886 \\
\hline $\begin{array}{l}\text { My buyer has benefited from the business relationship with me, } \\
\text { in my damage. }\end{array}$ & 2.51 & 1.27 & \\
\hline My buyer makes promises that does not hold. & 2.50 & 1.20 & \\
\hline $\begin{array}{l}\text { My buyer changes market conditions in order to benefit more } \\
\text { from me. }\end{array}$ & 2.80 & 1.32 & \\
\hline $\begin{array}{l}\text { My buyer break formal or informal agreements with me, } \\
\text { for his benefit. }\end{array}$ & 2.54 & 1.27 & \\
\hline Contracts & & & .823 \\
\hline $\begin{array}{l}\text { The business relationship with my buyer is governed by written } \\
\text { contracts. }\end{array}$ & 2.19 & 1.40 & \\
\hline $\begin{array}{l}\text { My buyer and I have written agreements detailing the obligations, } \\
\text { the rights of the parties and the consequences for its termination. }\end{array}$ & 2.23 & 1.38 & \\
\hline I and my buyer do not formalize our agreement through a contract. & 3.32 & 1.60 & \\
\hline Performance & & & .859 \\
\hline Sales revenue & 3.36 & 0.92 & \\
\hline Herd size & 3.74 & 0.89 & \\
\hline Production costs & 3.20 & 1.00 & \\
\hline
\end{tabular}

curacy, timing, sufficiency or reliability of the shared information (Monczka et al., 1998). It is true that information sharing is important, but the importance of its impact on the chain will depend on the information that is shared and with whom this information is shared (Chizzo, 1998; Holmberg, 2000).

Given the risk of voluntarily distorted infor- mation (Grundvåg Ottesen, 2006) from different actors in the chain, ensuring information quality becomes a very important element $(\mathrm{Li}$ et al., 2005). The proposed hypothesis for information quality is:

Hypothesis 5: Information quality between farmers and their buyers is positively associated with farm's performance. 
Figure 1 - The hypothesized model.

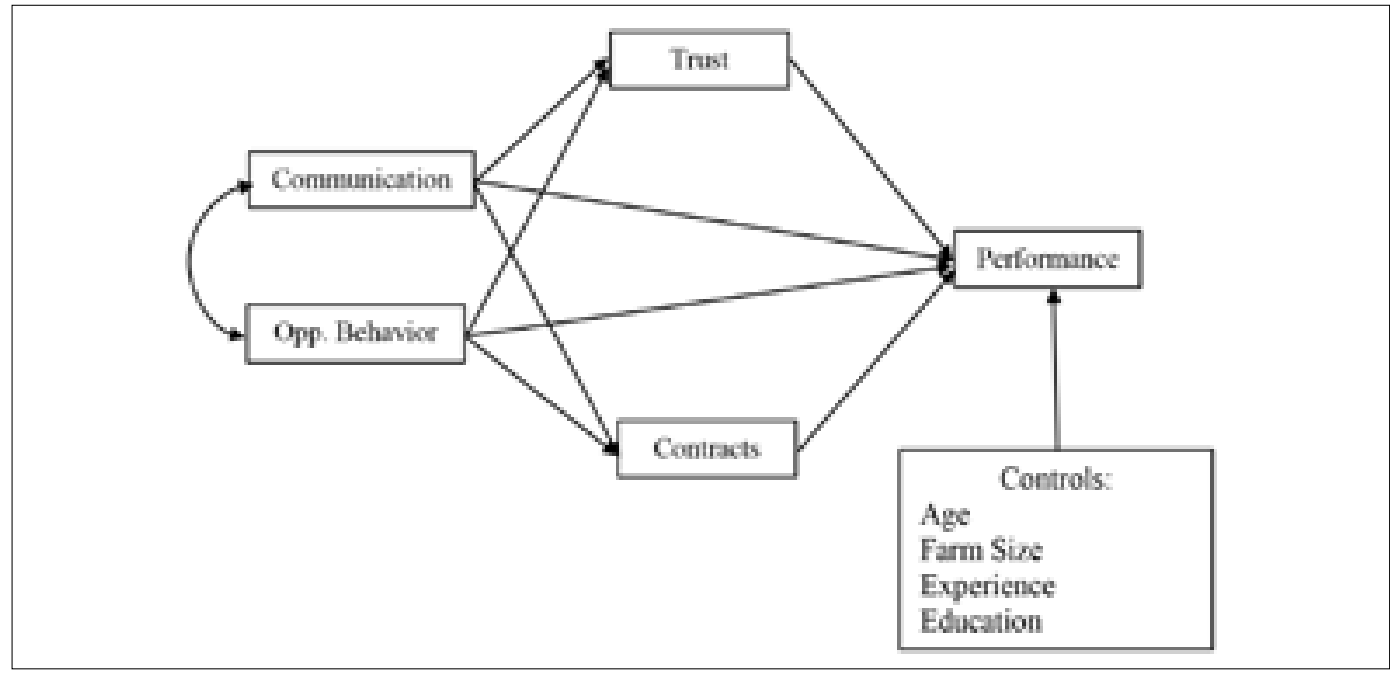

After preliminary data analysis, information sharing and information quality, two of the factors discussed above, have been merged together to give a new single factor called communication. Therefore, the new hypothesis that this study raise is the following:

Hypothesis 6: Communication between farmers and their buyers is positively associated with farm's performance.

Based on the discussion so far, the proposed study framework is presented in Figure 1, which represents the structural equation model of the research hypotheses previously outlined.

In order to consider potentially confounding variables, in the model were introduced some control variables. The control variables are:

a) Age (measured in number of years).

b) Farm size (measured in dynym ${ }^{1}$ ).

c) Farmers' experience (measured in number of years).

d) Farmers' education level (measured in number of years).

\section{Materials and methods}

\subsection{Data collection and sample}

Data were collected via a three-section questionnaire with close-ended questions. The first section aimed to collect general information of the farm: location, farm size, the significance of the livestock activities on the farm. Also, in this part of the questionnaire was collected information on the farm manager: gender, age, education, the number of years dealing with livestock. This information was gathered because was evaluated that these elements could have an effect on the farm's performance. The second section collected information about livestock activity on the farm, and the third section addressed the assessment of non-financial factors affecting the farm performance, using a five-point Likert scale ranging from 1 (strongly disagree) to 5 (strongly agree). A total of 201 questionnaires were completed in three main regions of Albania; Tirana, Korça and Lushnje. These regions were selected due to the large number of livestock farms that these regions have.

\subsection{Measurement and construct validation}

Confirmatory Factor Analysis (CFA) was performed in AMOS 21. The model, have a good level of goodness of fit (Chi-square $=324.956$; $\mathrm{df}=194 ; \mathrm{p}=.000 ; \mathrm{CMIN} / \mathrm{DF}=1.675 ; \mathrm{CFI}=$ 0.977 , $\operatorname{RMSEA}=0.05$; $\mathrm{TLI}=0.972$ ).

$1 / 10$ of a hectare. 
Table 2 - Validity and reliability.

\begin{tabular}{|l|c|c|c|c|}
\hline & $C R$ & $A V E$ & $M S V$ & MaxR(H) \\
\hline Performance & 0.871 & 0.696 & 0.009 & 0.963 \\
\hline Trust & 0.981 & 0.929 & 0.429 & 0.990 \\
\hline Opp. Behavior & 0.892 & 0.683 & 0.056 & 0.993 \\
\hline Contracts & 0.963 & 0.929 & 0.146 & 0.994 \\
\hline Communication & 0.732 & 0.581 & 0.429 & 0.994 \\
\hline
\end{tabular}

Note: CR - Composite Reliability, AVE - Average Variance Extracted, MSV-Maximum Shared Variance, MaxR - Maximum Reliability.

Table 3 - Factor correlation matrix with the square root of the AVE on the diagonal.

\begin{tabular}{|l|c|c|c|c|c|}
\hline & Performance & Trust & Opp. Behavior & Contracts & Communication \\
\hline Performance & 0.834 & & & & \\
\hline Trust & 0.094 & 0.964 & & & \\
\hline Opp. Behavior & 0.017 & -0.193 & 0.826 & & \\
\hline Contracts & 0.029 & 0.278 & -0.081 & 0.964 & \\
\hline Communication & -0.046 & 0.655 & -0.237 & 0.382 & 0.763 \\
\hline
\end{tabular}

Table 2 shows the results of reliability and validity of the measured constructs. Reliability will be analyzed based on the composite reliability (CR) values. Bagozzi et al. (1991) suggested that the minimum value of $\mathrm{CR}$ is 0.6 . The results presented in Table 3 show that each construct has CR greater than the suggested threshold value of 0.6 , in this way we conclude that reliability is achieved.

Convergent validity will be analyzed through AVE (Average Variance Extracted), as it is a strict measure of convergent validity. Malhotra and Dash (2011) would emphasize that AVE is a much more conservative measure of convergent validity than $\mathrm{CR}$. The suggested threshold value for AVE is 0.5 (Hair et al., 2010). The results presented in Table 2 show that each construct has AVE greater than the suggested threshold value of 0.5 , in this way it can be concluded that the constructs fulfil the condition of convergent validity. On discriminant validity, Hair et al. (2010) suggest that the three threshold values to prove discriminant validity are: a) AVE > MSV, b) AVE > $\mathrm{ASV}, \mathrm{c})$ square root of AVE greater than inter-construct correlations. Based on the results of the Table 2 and Table 3, it can be seen that the threshold values suggested by Hair et al. (2010) are achieved, the constructs also fulfil the condition of discriminant validity.

\section{Results}

The hypothesized structural model results with a very good fit (chi-square $=19.005$; $\mathrm{df}=13$; $\mathrm{p}=.123 ; \mathrm{CMIN} / \mathrm{DF}=1.462 ; \mathrm{CFI}=0.982, \mathrm{RM}-$ $\mathrm{SEA}=0.048$ and TLI $=0.95)$. Given the good fit of the model, the hypothesis was assessed by analyzing the estimated structural coefficients shown in Table 4.

As Table 4 shows, the hypothesis one (H1) regarding trust is supported, so trust has a significant positive effect on farm performance. Hypotheses two (H2) and three (H3) on contract and opportunistic behavior are not supported, so these factors have an insignificant effect on performance. While the result of the sixth hypothesis (H6) shows that communication has a significant negative effect on performance.

Also, referring to Table 4, of the four control variables used in this model only farm size and age have a significant effect on farm performance, while experience and education level do not significantly affect farm performance. 
Table 4 - Structural model results.

\begin{tabular}{|l|l|l|l|c|c|c|c|c|}
\hline $\begin{array}{c}\text { Hypothesis } \\
(H)\end{array}$ & & & & Estimate & Std-Estimate & S.E. & C.R. & $P$ \\
\hline $\mathrm{H} 1$ & Performance & $\leftarrow$ & Trust & 0.259 & 0.306 & 0.082 & 3.164 & 0.002 \\
\hline $\mathrm{H} 2$ & Performance & $\leftarrow$ & Contracts & 0.031 & 0.047 & 0.050 & 0.616 & 0.538 \\
\hline $\mathrm{H} 3$ & Performance & $\leftarrow$ & Opp. Behavior & -0.010 & -0.014 & 0.052 & -0.198 & 0.843 \\
\hline $\mathrm{H} 6$ & Performance & $\leftarrow$ & Communication & -0.426 & -0.308 & 0.145 & -2.944 & 0.003 \\
\hline Controls & Performance & $\leftarrow$ & Age & -0.011 & -0.136 & 0.006 & -1.727 & 0.084 \\
\hline Controls & Performance & $\leftarrow$ & Farm size & 0.127 & 0.172 & 0.055 & 2.314 & 0.021 \\
\hline Controls & Performance & $\leftarrow$ & Experience & -0.006 & -0.067 & 0.007 & -0.826 & 0.490 \\
\hline Controls & Performance & $\leftarrow$ & Education & -0.010 & -0.041 & 0.018 & -0.560 & 0.575 \\
\hline- & Trust & $\leftarrow$ & Communication & 1.166 & 0.714 & 0.083 & 14.090 & $* * *$ \\
\hline- & Trust & $\leftarrow$ & Opp. Behavior & -0.004 & -0.004 & 0.045 & -0.080 & 0.936 \\
\hline Controls & Trust & $\leftarrow$ & Education & 0.029 & 0.098 & 0.014 & 2.011 & 0.044 \\
\hline- & Contracts & $\leftarrow$ & Trust & -0.068 & -0.050 & 0.116 & -0.557 & 0.578 \\
\hline- & Contracts & $\leftarrow$ & Communication & 0.995 & 0.471 & 0.193 & 5.159 & $* * *$ \\
\hline- & Contracts & $\leftarrow$ & Opp. Behavior & 0.007 & 0.006 & 0.074 & 0.091 & 0.927 \\
\hline Controls & Contracts & $\leftarrow$ & Farm size & 0.053 & 0.047 & 0.078 & 0.681 & 0.496 \\
\hline Controls & Contracts & $\leftarrow$ & Experience & -0.024 & -0.172 & 0.009 & -2.748 & 0.006 \\
\hline Controls & Contracts & $\leftarrow$ & Education & -0.026 & -0.070 & 0.026 & -1.027 & 0.304 \\
\hline
\end{tabular}

Note: ${ }^{* * *}$ significant at $p<.001$.

\subsection{Mediation}

Since SEM provides a general and flexible framework for conducting mediation analysis (Gunzler et al., 2013) the following hypothesis is proposed:

Hypothesis 7: Trust mediates the positive effect of communication between farmers and buyers on the farm's performance.

The result of the mediation effect it is shown in the Table 5. Zhao et al. (2010) point out that the only on requirement to confirm mediation is to have a significant indirect effect. They continued their discussion by suggesting the use of bootstrap to prove the importance of the indirect effect as a more rigorous procedure compared to the Sobel test.
As shown in Table 5, trust mediates the positive effect of communication on the performance. Referred to Zhao et al. (2010) mediation type is competitive mediation since the mediated and direct effect both exist, but have opposite directions.

\section{Discussion and conclusions}

It should be noted that livestock breeding is one of the main branches of agricultural development in Albania, contributing significantly in the country's GDP. This sector has had the biggest development during the transition years, being considered as a priority sector for development due to the country favorable livestock breeding conditions.

Table 5 - Mediation effects through bootstrapping.

\begin{tabular}{|c|c|c|c|c|}
\hline Hypothesis $(H)$ & Mediation Path & Indirect Effect & $P$ & Type of mediation \\
\hline $\mathrm{H} 7$ & Comm $\rightarrow$ Trust $\rightarrow$ Perfm & .302 & .009 & Competitive \\
\hline
\end{tabular}

Note: The type of mediation as classified by Zhao et al. (2010). Indirect effects are not standardized. Comm.Communication; Perfm. - Performance. 
This article aims to address the effects of non-financial factors on the performance of livestock farms in the meat supply chain in Albania. Literature has shown that the performance is affected by a number of non-financial factors, such as: trust, contracts, opportunistic behavior, information sharing and information quality Doney and Cannon (1997); Dasgupta (1998); Nevis and Money (2006); Lusch and Brown (1996); Weitz and Jap (1995); Williamson (1975); Monczka et al., (1998); Lalonde (1998); Prajogo and Olhager (2012).

Findings from this study show that there is a significant positive effect of trust on performance (H1). The result is in line with Nevis and Money (2006) who emphasized that trust is expected to have a positive direct impact in farm performance. In this case farmers believe in their buyer, believe that the buyer is trustworthy, that he keeps his promises, that does not make false promises and that does not take action that might harm their farm business. We can say that the result is in the same line also with Dasgupta (1998) according to which trust refers to the believe of an actor that the other party will fulfill his promises, and with Grewal et al. (1999) where trust among members on a chain is seen as an element that can lead to mutually satisfactory relationships in the long run.

Contracts were the second factor of which the impact on performance was tested, based on the work of Lusch and Brown (1996); Weitz and Jap (1995) who emphasized that the performance of marketing activities by members of a chain can be coordinated by clear and written agreements such as contracts. According to Nevis and Money (2006) contracts indicate how the involved parties should behave. Empirical findings showed that contracts had no direct effect in farm performance (H2). This means that farmers in the meat supply chain in Albania do not manage their business relationships through written contracts and that they do not have written agreements that detail the rights and obligations of the parties, as well as the consequences for their termination. This result is in line with Lusch and Brown (1996) who emphasized that various empirical studies were unable to find a link between contracts and performance; and with Nevis and Money (2006) who viewed the contracts as a factor that does not necessary directly affect the performance.

Opportunistic behavior is defined as a behavior in the pursuit of self-interest with stealing, lying, cheating, distorting, misleading (Williamson, 1975). Findings from this study show that the opportunistic behavior does not have an effect in farm performance (H3). This because the farmer did not accept that their buyer disrupted the deals for his benefit; or that changes market conditions in order to benefit more from them, or makes promises in connection with the business relationship that does not hold.

Communication was the fourth factor for which was tested its direct effect on performance. This factor was created by merging two other factors, information sharing and information quality. Prajogo and Olhager (2012) emphasized the importance of quantity and quality of the information that is exchanged among members of a chain. According to Huo et al. (2016) in a supply chain communication facilitates the sharing of sensitive information, which is very important in the realization of transactions and in the reduction of opportunism. The study findings show that there is a significant but negative effect of communication on performance (H6). The results indicate that farmers and their buyers share information with each other, but not necessarily the shared information is qualitative because it may be voluntarily distorted (Grundvåg Ottesen, 2006). The information may not be accurate, complete or correct.

Regarding the control variables, farm size and the farmer's age had a significant association with farm's performance. The result shows that farm size is positively associated with farm's performance, while farmer's age is negatively associated with performance. Data analysis shows that farmer's education is positively associated with trust, while his experience is negatively associated with contracts. Indeed, the study does not aim to analyze the effect of control variables on the factors taken into analysis, but these results may constitute an indication for future studies.

In addition, this study also estimated the indirect effect of communication on the perfor- 
mance of livestock farms through the mediation of trust for the fact that SEM provides a general and flexible framework for conducting mediation analysis (Gunzler et al., 2013).

It appears that trust mediates the positive effect of communication on performance $(\mathrm{H} 7)$. In this case, there is no voluntary distortion of the shared information as the relationship between the farmer and the buyer is based on the trust between them. While referring to the type of mediation, according to Zhao et al. (2010), the mediation is competitive mediation because both effects mediated and the direct effect of communication on performance does exist but have opposite directions.

\section{References}

Bagozzi R.P., Yi Y., Phillips L.W., 1991. Assessing construct validity in organizational research. $A d$ ministrative Science Quarterly, 36: 421-458.

Bojnec Š., Latruffe L., 2013. Farm size, agricultural subsidies and farm performance in Slovenia. Land Use Policy, 32: 207-217. https://doi.org/10.1016/j. landusepol.2012.09.016.

Bourne M., Neely A., Mills J., Platts K., 2003. Implementing performance measurement systems: a literature review. International Journal of Business Performance Management, 5(1): 1-24.

Cao M., Zhang Q., 2011. Supply chain collaboration: Impact on collaborative advantage and firm performance. Journal of Operations Management, 29(3): 163-180. https://doi.org/10.1016/j. jom.2010.12.008.

Chizzo S.A., 1998. Supply chain strategies: solutions for the customer-driven enterprise. Software Magazine. Supply Chain Management Directions Supplement, 1(1): 4-9.

Dasgupta P., 1998. Trust as a commodity. In: Gambetta D. (ed.), Trust: Making and Breaking Cooperative Relations. Oxford, UK: Blackwell, pp. 49-72.

Doney P.M, Cannon J., 1997. An Examination of the nature of trust in buyer-seller relationships. Journal of Marketing, 61(2): 35-51.

Fetoui M., Dhehibi B., Frija A., Sgaier A., Kassam S., Aw-Hassan A.A., Abdeladhim M.A., Sghaier M., 2020. Towards an innovative olive oil value chain: Options for inclusive development in South-Eastern Tunisia. New Medit, 19(3): 3-20.

Fynes B., Voss C., 2002. The moderating effect of buyer-supplier relationships on quality practices and performance. International Journal of Operations and Production Management, 22(6): 589613.

Ganesan S., 1994. Determinants of long-term orientation in buyer-seller relationships. Journal of Marketing, 58(2): 1-19.

Geyskens I., Steenkamp J.B.E.M., Scheer L.K., Kumar N., 1996. The effects of trust and interdependence on relationship commitment: A trans-Atlantic study. International Journal of Research in Marketing, 13(4): 303-317. https://doi.org/10.1016/S01678116(96)00006-7.

Grewal R., Comer J.M., Mehta R., 1999. Does trust determine satisfaction in marketing channel relationships? The moderating role of exchange partner's price competitiveness. Journal of Business to Business Marketing, 6: 1-18.

Grundvåg Ottesen G., 2006. Do upstream actors in the food chain know end-users' quality perceptions? Findings from the Norwegian salmon farming industry. Supply Chain Management, 11(5): 456-463. https://doi.org/10.1108/13598540610682471.

Gunasekaran A., Patel C., Tirtiroglu E., 2001. Performance Measures and Metrics in a Supply Chain Environment. International Journal of Operations and Production Management, 21(1/2): 71-87. https://doi.org/10.1108/01443570110358468.

Gunzler D., Chen T., Wu P., Zhang H., 2013. Introduction to mediation analysis with structural equation modelling. Shanghai Archives of Psychiatry, 25(6), 390-394.

Hair J.F. Jr., Black W.C., Rabin B.J., Anderson R.E., 2010. Multivariate data analysis. Upper Saddle River, NJ: Prentice Hall.

Holmberg S., 2000. A systems perspective on supply chain measurements. International Journal of Physical Distribution and Logistics Management, 30(10): 847-868.

Huo B., Wang Z., Tian Y., 2016. The impact of justice on collaborative and opportunistic behaviors in supply chain relationships. International Journal of Production Economics, 177: 12-23. https://doi. org/10.1016/j.ijpe.2016.04.006.

INSTAT, 2014. Agriculture Statistics. Retrieved from http://www.instat.gov.al/en/themes/agriculture-and-fishery/agriculture/publication/2015/ press-release-agriculture-statistics-2014/.

Jap S.D., Anderson E., 2003. Safeguarding interorganizational performance and continuity under ex post opportunism. Management Science, 49(12): 1684-1701.

Johnston D.A., McCutcheon D.M., Stuart F.I., Kerwood H., 2004. Effects of supplier trust on per- 
formance of cooperative supplier relationships. Journal of Operations Management, 22(1): 23-38. https://doi.org/10.1016/j.jom.2003.12.001.

Kim S.W., 2009. An investigation on the direct and indirect effect of supply chain integration on firm performance. International Journal of Production Economics, 119(2): 328-346. https://doi. org/10.1016/j.ijpe.2009.03.007.

Kipi A., Skreli E., Uruci M., Mersini K., 2010. Study of small ruminants sub-sector in Albania. A report from Albanian Dairy and Meat Association. Tirana, Albania.

Kirkwood J.B., 2005. Buyer Power and Exclusionary Conduct: Should Brooke Group Set the Standards for Buyer-Induced Price Discrimination and Predatory Bidding? Antitrust Law Journal, 72(2): 625-668.

Kristo I., Leonetti L., 2005. The Food Chain Structure of Small Ruminants Meat and Dairy Products in Albania, UNDP Project "Strengthening the Marketing of Small Ruminants". Tirana, Albania.

Lai C.-S., Liu S.-S., Yang C.-F., Lin H.-W., Tsai H.W., 2005. Governance Mechanisms of Opportunism: Integrating from Transaction Cost Analysis and Relational Exchange Theory. Taiwan Academy of Management Journal, 5(1): 1-24.

Lalonde B.J., 1998. Building a supply chain relationship. Supply Chain Management Review, 2(2): 7-8.

Latruffe L., Piet L., 2014. Does land fragmentation affect farm performance? A case study from Brittany, France. Agricultural Systems, 129: 68-80. https:// doi.org/10.1016/j.agsy.2014.05.005.

Lee H.L., So K.C., Tang C.S., 2000. The value of information sharing in a two-level supply chain. Management Science, 46(5): 626-643.

Li S., Rao S.S., Ragu-Nathan T.S., Ragu-Nathan B., 2005. Development and validation of a measurement instrument for studying supply chain management practices. Journal of Operations Management, 23(6): 618-641. https://doi.org/10.1016/j. jom.2005.01.002.

Lusch R.F., Brown J.R., 1996. Interdependency, contracting, and relational behavior in marketing channels. Journal of Marketing, 60(4): 19-39.

MacNeil I.R., 1981. Economic Analysis of Contractual Relations: Its Shortfalls and the Need for a 'Rich Classificatory Apparatus. Northwestern University Law Review, 75(2): 1018-1063.

Malhotra N.K., Dash S., 2011. Marketing Research an Applied Orientation. London: Pearson Publishing. Markhof M., Musabelliu B., Zusi A., 2010. Meat Sec- tor Study in Albania. Technical Report for the Project: Capacity Building for Implementing the Rural Development Strategy. Tirana, Albania.

Marshall C.C., Bly S., 2005. Sharing Encountered Information: Digital Libraries Get a Social Life. In: JCDL '04: Proceedings of the $4^{\text {th }}$ ACM/IEEE joint conference on Digital libraries, pp. 218-227. Retrieved from http://ieeexplore.ieee.org/xpls/abs_all. jsp?arnumber $=1336125$.

Meço M., Mehmeti G., Murrja A., Tomorri I., Maloku S., 2017. Farm Management, $2^{\text {nd }}$ ed. Botimet Male. Monczka R., Trent R., Handfield R., 1998. Purchasing and Supply Chain Management. Cincinnati, Ohio: South-Western College Pub.

Mondher F., Boubaker D., Aymen F., Abderrahman S., Shinan K., Aden A.A.-H., Mohamed A.A., Mongi S., 2020. Towards an innovative olive oil value chain: Options for inclusive development in South-Eastern Tunisia. New Medit, 19(3): 2-20.

Morgan R.M., Hunt S.D., 1994. The commitment-trust theory of relationship marketing. Journal of Marketing, 58(3): 20-38.

Nevis J.L., Money R.B., 2006. Performance implications of distributor effectiveness, trust, and culture in import channels of distribution. Industrial Marketing Management, 37: 46-58.

Prajogo D., Olhager J., 2012. Supply chain integration and performance: The effects of long-term relationships, information technology and sharing, and logistics integration. International Journal of Production Economics, 135(1): 514-522. https:// doi.org/10.1016/j.ijpe.2011.09.001.

Sorrentino A., Russo C., Cacchiarelli L., 2018. Market power and bargaining power in the EU food supply chain: the role of Producer Organizations. New Medit, 17(4): 21-31.

Weitz B.A., Jap S.D., 1995. Relationship marketing in distribution channels. Journal of the Academy of Marketing Science, 23(4): 305-320.

Williamson O.E., 1975. Markets and Hierarchies: Analysis and Antitrust Implications. New York: Free Press.

Xhoxhi O., Keco R., Skreli E., Imami D., Musabelliu B., 2019. The role of intermediaries' power on contracting decision between farmers and intermediaries. New Medit, 18(3): 3-15.

Zhao X., Lynch J.G., Chen Q., 2010. Reconsidering Baron and Kenny: Myths and Truths about Mediation Analysis. Journal of Consumer Research, 37(2): 197-206. 